\title{
Activation of Axonal Receptors by GABA Spillover Increases Somatic Firing
}

\author{
Jason R. Pugh and Craig E. Jahr \\ Vollum Institute, Oregon Health and Science University, Portland, Oregon 97239
}

Axons can be depolarized by ionotropic receptors and transmit subthreshold depolarizations to the soma by passive electrical spread. This raises the possibility that axons and axonal receptors can participate in integration and firing in neurons. Previously, we have shown that exogenous GABA depolarizes cerebellar granule cell axons through local activation of $\mathrm{GABA}_{\mathrm{A}}$ receptors $\left(\mathrm{GABA}_{\mathrm{A}} \mathrm{Rs}\right)$ and the soma through electrotonic spread of the axonal potential resulting in increased firing. We show here that excitability of granule cells is also increased by release of endogenous GABA from molecular layer interneurons (MLIs) and spillover activation of parallel fiber $\mathrm{GABA}_{\mathrm{A}} \mathrm{Rs}$ in mice and rats. Changes in granule cell excitability were assessed by excitability testing after activation of MLIs with channelrhodopsin or electrical stimulation in the molecular layer. In granule cells lacking an axon, excitability was not changed, suggesting that axonal receptors are required. To determine the distance over which subthreshold potentials may spread, we estimated the effective axonal electrical length constant $(520 \mu \mathrm{m})$ by excitability testing and focal uncaging of RuBi-GABA on the axon at varying distances from the soma. These data suggest that $\mathrm{GABA}_{\mathrm{A}} \mathrm{R}$-mediated axonal potentials can participate in integration and firing of cerebellar granule cells.

\section{Introduction}

Traditionally, processing and integration of electrical signals in neurons is thought to take place in the dendrites, soma, and axon initial segment, whereas the axon simply transmits action potentials (APs) to synaptic terminals. However, recent evidence suggests that the axon may also be involved in modulation and integration of electrical signals. Several groups have shown that somatic subthreshold depolarizations can spread passively out the axon for hundreds of micrometers influencing transmitter release (Alle and Geiger, 2006; Shu et al., 2006; Christie et al., 2011). However, subthreshold depolarizations can also be generated locally in the axon by activation of ionotropic receptors (Eccles, 1964; Schmitz et al., 2001; Turecek and Trussell, 2001; Ruiz et al., 2003; Pugh and Jahr, 2011), and cable properties of an unbranched axon predict that depolarizations initiated in the axon will also spread back toward the soma. This raises the possibility that synaptic potentials generated in the axon can travel antidromically to the soma and integrate with somatodendritic potentials to affect firing. If true, axons and axonal receptors may participate in the input stages of neuronal processing and influence the spike output of neurons in conjunction with dendrites and dendritic receptors.

We investigated this possibility by studying the activation of $\mathrm{GABA}_{\mathrm{A}}$ receptors $\left(\mathrm{GABA}_{\mathrm{A}} \mathrm{Rs}\right)$ expressed in the axons of cerebellar

Received July 1, 2013; revised Sept. 9, 2013; accepted Sept. 17, 2013.

Author contributions: J.R.P. and C.E.J. designed research; J.R.P. performed research; J.R.P. analyzed data; J.R.P. and C.E.J. wrote the paper.

This work was supported by National Institutes of Health Grant NS066037. We thank the Jahr laboratory members for discussions and critical readings of this manuscript.

Correspondence should be addressed to Craig E. Jahr, Vollum Institute L474, Oregon Health and Science University, 3181 SW Sam Jackson Park Road, Portland, 0R 97239. E-mail: jahr@ohsu.edu.

J. R. Pugh's present address: The University of Texas Health Science Center at San Antonio, South Texas Research Facility, MSC 8756, Department of Physiology, 8403 Floyd Curl Drive, San Antonio, TX 78229-3904.

DOI:10.1523/JNEUROSCI.2796-13.2013

Copyright $\odot 2013$ the authors $\quad 0270-6474 / 13 / 3316924-06 \$ 15.00 / 0$ granule cells, which form the parallel fibers. It is well established that parallel fibers express functional $\mathrm{GABA}_{\mathrm{A}} \mathrm{Rs}$, that their activation depolarizes the axon, and that they increase release probability at parallel fiber synapses (Stell et al., 2007; Pugh and Jahr, 2011; Stell, 2011; Dellal et al., 2012). Previous experimental studies applying exogenous GABA to granule cell axons by iontophoresis (Pugh and Jahr, 2011) and computer modeling studies (Dellal et al., 2012) have suggested that $\mathrm{GABA}_{\mathrm{A}} \mathrm{R}$-mediated axonal depolarizations can also increase the probability of AP firing near the soma. However, the time course and concentration of GABA resulting from spillover from neighboring inhibitory synapses is likely very different from that produced by iontophoresis. Therefore, it remains unclear whether axonal receptors can participate in integration and firing when activated by endogenous GABA.

In the present work, we provide evidence that granule cell axons transduce signals generated by neurotransmitter release from other neurons through receptor activation, membrane depolarization, and passive electrical spread from the axon to the soma. We demonstrate that activation of molecular layer interneurons (MLIs) by either channelrhodopsin 2 (ChR2) or electrical stimulation influences granule cell firing by activating axonal $\mathrm{GABA}_{\mathrm{A}}$ Rs. Furthermore, we find that subthreshold depolarizations can passively spread for hundreds of micrometers from the axon back to the soma.

\section{Materials and Methods}

Acute horizontal brain slices were prepared from the cerebella of male and female P14-P19 Sprague Dawley rats or P20-P28 (PvalbCOP $4 \times$ H134R/EYFP; The Jackson Laboratory) mice as described previously (Pugh and Jahr, 2011). Slices were superfused with ACSF (in mM: $119 \mathrm{NaCl}, 26.2 \mathrm{NaHO}_{3}, 2.5 \mathrm{KCl}, 1 \mathrm{NaH}_{2} \mathrm{PO}_{4}, 1.3 \mathrm{MgCl}_{2}, 2 \mathrm{CaCl}_{2}$, and 11 glucose) containing $10 \mu \mathrm{M}$ NBQX (Ascent Scientific), $5 \mu \mathrm{M} 3-((R)-2-$ carboxypiperazine-4-yl)-propyl-1-phosphonic acid ( $R$-CPP; Ascent Scientific), and 1-5 $\mu \mathrm{M}$ CGP55845 [(2S)-3-[(15)-1-(3,4-dichlorophenyl) 
A GC axonal GABA ionto

\section{B GC somatic excitability}
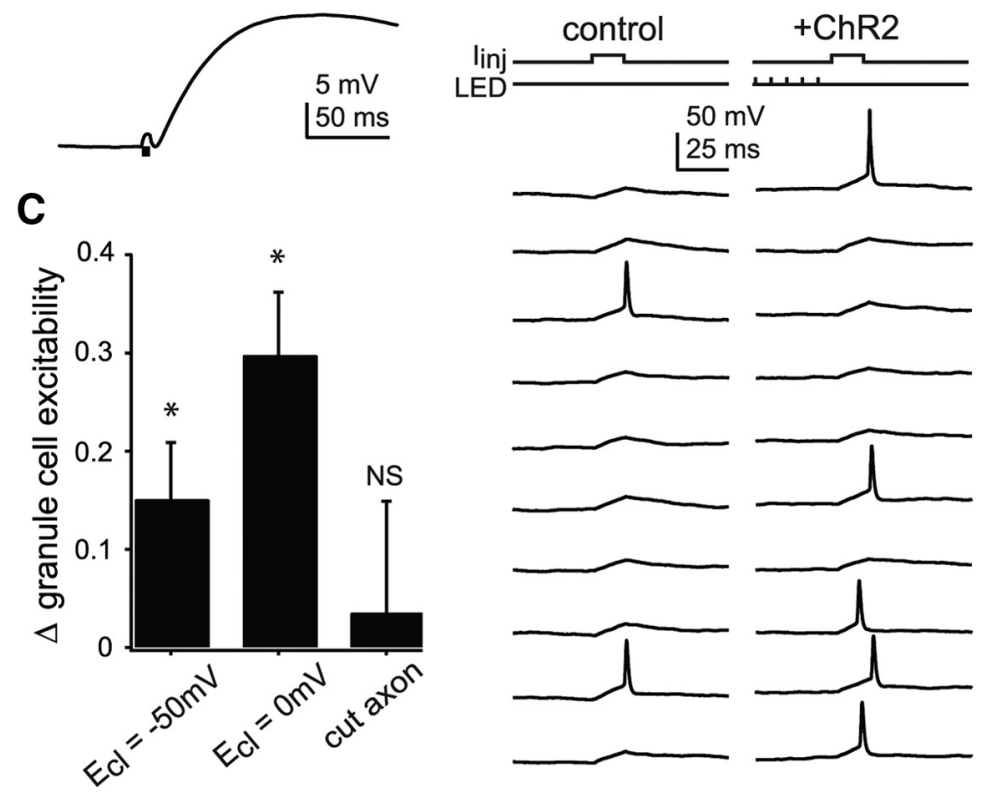

D MLI ChR2 excitability
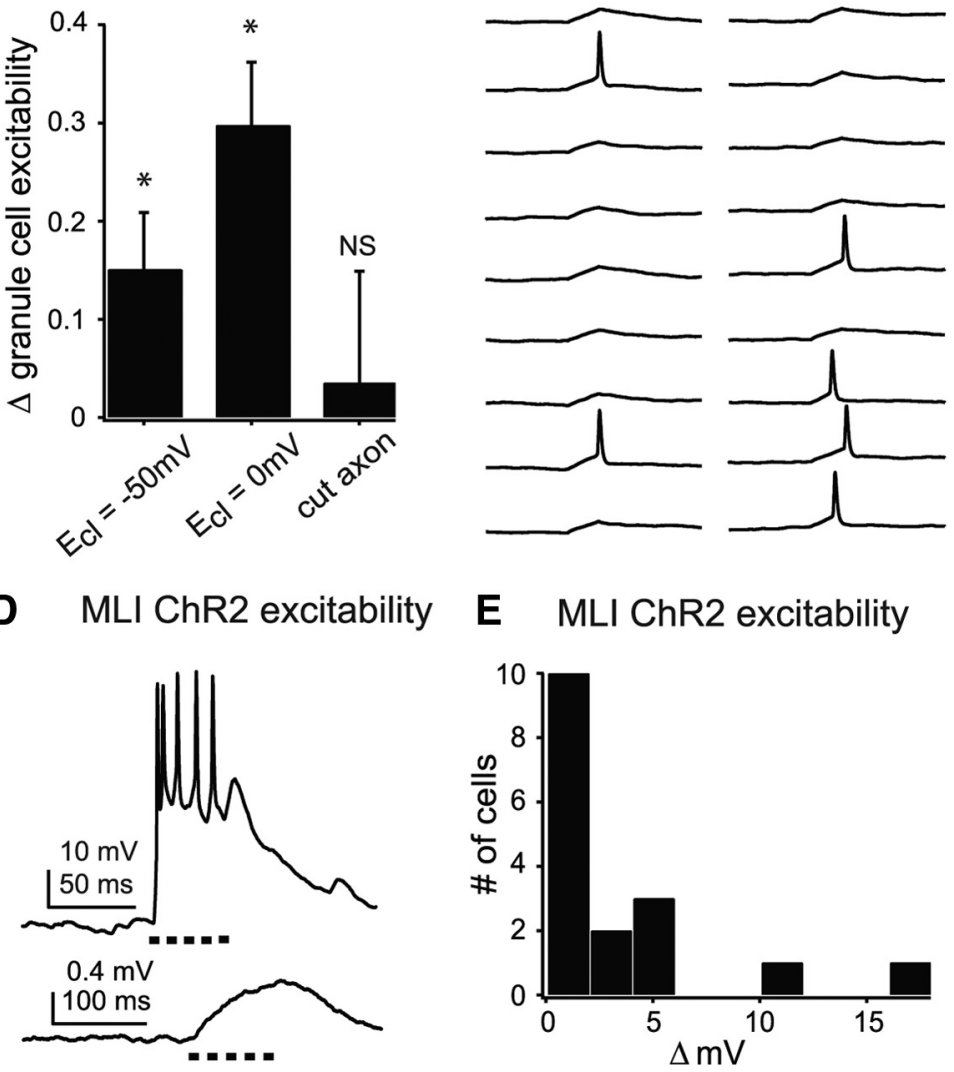

Figure 1. Activation of MLIs by ChR2. A, Average depolarization measured at a granule cell (GC) soma after brief (5 ms) iontophoretic (ionto) application of GABA onto the axon $170 \mu \mathrm{m}$ from the soma. $\boldsymbol{B}$, Excitability testing protocol (top) and 10 consecutive pairs of interleaved control (left) and ChR2 (right) sweeps. Inj, Injection. C, Average excitability index from cells with an intact axon using intracellular solutions with a calculated $E_{C_{1}}$ of $-50 \mathrm{mV}$ (left) or $\sim 0 \mathrm{mV}$ (middle) or cells lacking an axon ( $E_{C 1}$ of $\sim 0$ $\mathrm{mV}$ ) (right). ${ }^{*} p<0.05$; NS, not significant. $\boldsymbol{D}$, Example MLI voltage responses to ChR2 activation. $\boldsymbol{E}$, Frequency histogram of ChR2-evoked depolarizations in MLIs.

ethyl] amino-2-hydroxypropyl)(phenylmethyl)

phosphinic acid; Tocris Bioscience] except when noted. When indicated, solutions also contained $100 \mu \mathrm{m}$ picrotoxin (Tocris Bioscience) or $500 \mathrm{~nm}$ TTX (Sigma).

Granule cells were patched using borosilicate pipettes (4-6M $\Omega$ ) containing the following: for high-chloride internal solution $\left(E_{\mathrm{Cl}}\right.$ of $\left.\sim 0 \mathrm{mV}\right)$, $140 \mathrm{~mm} \mathrm{KCl}, 4 \mathrm{~mm} \mathrm{MgCl} 2,10 \mathrm{~mm}$ HEPES, 4 mm Na-ATP, and $0.5 \mathrm{~mm}$ $\mathrm{Na}$-GTP; for medium-chloride internal solution $\left(E_{\mathrm{Cl}}\right.$ of $\left.-50 \mathrm{mV}\right), 134$ mM K-gluconate, $10 \mathrm{~mm} \mathrm{KCl}, 4 \mathrm{~mm} \mathrm{MgCl}_{2}, 10 \mathrm{~mm}$ HEPES, $4 \mathrm{~mm}$ Na-ATP, $0.5 \mathrm{~mm} \mathrm{Na-GTP,} \mathrm{and} 50 \mu \mathrm{m}$ Alexa Fluor 594 (Invitrogen). Electrophysiological currents and potentials were recorded with a Multiclamp 700B amplifier (Molecular Devices), filtered at $5 \mathrm{kHz}$, and digitized at $20-50 \mathrm{kHz}$. ChR2 was activated by full-field illumination from a $470 \mathrm{~nm}$ LED (Thorlabs). The LED power measured under the objective was $6-7 \mathrm{~mW}$. In five cells, we compared the photo-current produced by the LED light with currents produced by a $473 \mathrm{~nm}$ laser (laser was set to produce either 1.7 or $9 \mathrm{~mW}$ of power as measured under the objective). The photo-currents produced by the LED were nearly identical to those produce by the laser at the highest power (LED, $3.4 \pm 1.9 \mathrm{pA}$; laser, $3.7 \pm$ $2 \mathrm{pA} ; p=0.4$, paired $t$ test), suggesting that LED illumination activated ChR2 to an extent similar to that reported by others (Hull and Regehr, 2012), close to maximally.
Excitability testing was performed on either the axon or soma of cerebellar granule cells (Pugh and Jahr, 2011). APs were elicited at the soma by a $15 \mathrm{~ms}$ current injection or in the axon by voltage pulses $(100 \mu \mathrm{s}, 10-80 \mathrm{~V})$ through an extracellular glass electrode. The intensity was adjusted to elicit APs in $<50 \%$ of the sweeps. Control sweeps consisting of a single stimulus alone (current injection or axonal stimulus) were interleaved with test sweeps consisting of the same stimulus preceded by a train of light pulses to activate ChR2, electrical stimulation of the molecular layer, or a small depolarization of the soma. Excitability was measured by calculating the success rate, defined as the proportion of sweeps in which an AP was produced, for each condition (Pugh and Jahr, 2011). Although success rate is a straightforward and effective method for determining a change in excitability between conditions, it is a poor method for quantifying the magnitude of those changes. The magnitude of change in excitability as measured by success rate is extremely sensitive to the ability of the experimenter to keep the stimulus near threshold (i.e., a stimulus significantly below threshold will produce a long run of failures, making it appear that there is little or no change in success rate, whereas a stimulus close to threshold will produced a larger change in success rate in the same conditions). To quantify changes in excitability more accurately, we also calculated an excitability index for each experiment. To do this, consecutive pairs of sweeps (one control and one test sweep) were considered a single trial. For each experiment, the number of trials with a failure in the control sweep and a success in the test sweep (FS trials) or a success in the control sweep and a failure in the test sweep (SF trials) were counted. Trials consisting of two successes or two failures were ignored because these trials contain no information about the relative excitability of the cell and can skew the data when the stimulus is far above or below threshold. The excitability index was calculated by measuring the difference between the number of FS and SF trials as a proportion of the total number of trials consisting of both a success and a failure: Excitability index $=(F S-S F) /(F S$ $+\mathrm{SF}$ ). An excitability index of 0 indicates no change in excitability (i.e., there were an equal number of FS and SF trials), whereas an excitability index of 1 or -1 indicates a maximal increase or decrease in excitability (i.e., all FS or all SF trials). Because experiments with a small number or FS or SF trials are prone to error attributable to random variability, we limited our analysis to experiments that had at least $10 \mathrm{FS}$ and SF trials (across all experiments, the number of such trials ranged from 10 to 54, with an average of 22 per experiment).

To measure the length constant of granule cell axons, we paired excitability testing on the axon at varying distances from the soma with small somatic depolarizations. To reduce variability, the soma was voltage clamped at $-70 \mathrm{mV}$. APs could be elicited by axonal stimulation because of poor space clamp in the axon and recorded as action currents at the soma. For each cell, a range of small somatic voltage steps $(0.5,1,2,3$, and $5 \mathrm{mV})$ were tested. Voltage steps of $0.5 \mathrm{mV}$ had no effect on excitability beyond $\sim 500 \mu \mathrm{m}$, whereas voltage steps of 3 or $5 \mathrm{mV}$ produced maximal effects on excitability at distances less than $\sim 500 \mu \mathrm{m}$. Therefore, we averaged effects from 1 and $2 \mathrm{mV}$ steps for each stimulus location.

GABA was locally applied through photolytic uncaging of RuBiGABA or iontophoresis. In uncaging experiments, $100 \mu \mathrm{M}$ RuBi-GABA 
was included in a recirculating bath solution and photolytically uncaged by $5 \mathrm{~ms}$ light pulses from a $473 \mathrm{~nm}$ laser or a $470 \mathrm{~nm}$ LED with the aperture closed down to produce an $\sim 20-30$ $\mu \mathrm{m}$ spot at the surface of the slice. Five millisecond light pulses were used to maximize GABAergic responses in the axon and to mimic the relatively slow "spillover" GABA transient experienced by parallel fiber $\mathrm{GABA}_{\mathrm{A}}$ Rs. The axon of the patched granule cell was visualized with two-photon laser-scanning microscopy (2PLSM), and the uncaging spot was positioned over the axon at $\sim 100 \mu \mathrm{m}$ intervals from the soma. The membrane potential at the soma was measured after uncaging of GABA at each position on the axon. To assess the spatial extent of uncaging, we also uncaged GABA at locations in which no labeled cellular process could be seen. Using the blue laser, no voltage response was observed when uncaging $100 \mu \mathrm{m}$ away from the soma $(-0.1 \pm 0.2 \mathrm{mV}, n=5)$. However, when using the LED, small voltage responses were detected at the soma $(100 \mu \mathrm{m}$ from soma, $1.1 \pm 0.4 \mathrm{mV}, n=8$ ) and subsequently subtracted from voltage responses after uncaging directly over the axon at the same distance from the soma. GABA iontophoresis was performed as described by Pugh and Jahr (2011).

2PLSM was performed on a customized Olympus upright microscope and a titanium: sapphire laser (Coherent) tuned to 810 or 840 $\mathrm{nm}$. Photomultipliers (H8224PA-40 or H10770PA-40; Hamamatsu) collected red light in the transfluorescence pathway.

Data are reported as mean \pm SE. Stimulus artifacts were digitally reduced in membrane current/voltage traces.

\section{Results}

Whole-cell patch-clamp recordings were made from cerebellar granule cells using a high-chloride $\left(E_{\mathrm{Cl}}\right.$ of $\sim 0 \mathrm{mV}$ ) internal solution containing $50 \mu \mathrm{M}$ Alexa Fluor 594 to visualize the cell morphology. As reported previously (Pugh and Jahr, 2011), application of exogenous GABA by iontophoresis near the labeled parallel fiber produced a depolarization in the axon that could be measured at the soma $(5.8 \pm 2.8 \mathrm{mV}, n=5$; Fig. $1 A)$ and an increase in excitability. To test whether activation of axonal $\mathrm{GABA}_{\mathrm{A}}$ Rs by synaptically released GABA can also modulate AP initiation, it was necessary to selectively activate axonal $\mathrm{GABA}_{\mathrm{A}}$ Rs while keeping somatodendritic receptors inactive. To achieve this goal, we took two complimentary approaches. First, we selectively evoked GABA release in the molecular layer (which contains granule cell axons but not somata or dendrites) using a transgenic mouse line expressing ChR2 in MLIs. Second, we activated GABAergic interneurons throughout the cerebellar cortex by electrical stimulation while blocking somatodendritic $\mathrm{GABA}_{\mathrm{A}}$ Rs by puffing picrotoxin onto the soma.

\section{Activation of MLIs by ChR2}

To evoke GABA release from MLIs in the molecular layer without activation of Golgi cells, we used a mouse line expressing ChR2 fused to yellow fluorescent protein (YFP) under a parvalbumin promoter. In these mice, YFP expression was evident throughout the molecular layer but absent from the granule cell layer, consistent with previ-
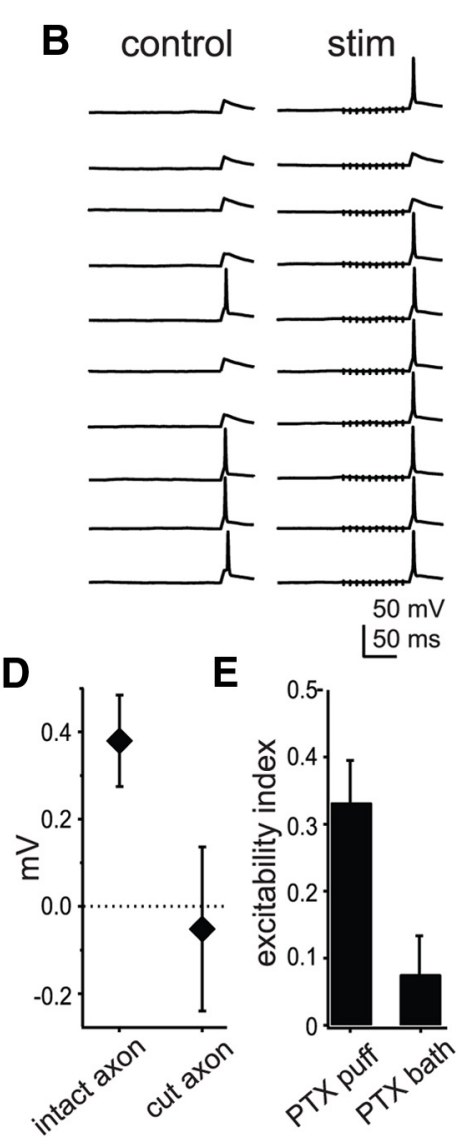

Figure 2. Activation of MLIs by electrical stimulation. A, Stimulus protocol (top) and voltage traces recorded from a granule cell Inset, Response to molecular layer stimulation at increased gain. inj, Injection; stim, stimulation. $\boldsymbol{B}$, Ten consecutive pairs of at increased gain. D Average depolarization at the soma in the presence of puffed picrotoxin during molecular layer stimulation in cells with intact or cut axons. $\boldsymbol{E}$, Average excitability index with soma or bath picrotoxin.

ously reported expression patterns (Zhao et al., 2011; Hull and Regehr, 2012).

The effect of MLI activation on granule cell firing was assessed by excitability testing. After confirming the presence of an intact axon, a depolarizing current injection $(15 \mathrm{~ms})$ was paired on alternating sweeps with a train of five light pulses $(2 \mathrm{~ms})$ at $50 \mathrm{~Hz}$ from a $470 \mathrm{~nm}$ LED to evoke GABA release from MLIs. APs were elicited less often during control sweeps (LED off) than in test sweeps (LED on), indicating an increase in excitability (success rate, $0.40 \pm 0.02$ vs $0.50 \pm 0.02, n=8, p=0.003$; Fig. $1 B, C)$. The excitability index, a more quantitative measure of the change in excitability between control and test conditions (see Materials and Methods), for these cells was $0.3 \pm 0.06$ ( $p=0.002$, onesample $t$ test), indicating that synaptic GABA release significantly increases somatic excitability. This change in excitability was blocked by bath application of $100 \mu \mathrm{M}$ picrotoxin (excitability index, $0.26 \pm 0.09$ vs $-0.05 \pm 0.03, n=4, p=0.04$ ). In cells lacking an axon, activation of MLIs by ChR2 had no effect on excitability (success rate, $0.57 \pm 0.05$ vs $0.58 \pm 0.04, n=5, p=$ 0.7 ; excitability index, $0.04 \pm 0.11$; Fig. $1 C$ ). The excitability index of cells lacking an axon was significantly different from cells with an intact axon ( $p=0.03$, unpaired $t$ test), confirming that the change in excitability results from axonal and not somatodendritic $\mathrm{GABA}_{\mathrm{A}}$ Rs. Previous work suggests that $E_{\mathrm{Cl}}$ in parallel fibers is depolarized from rest, near AP threshold (Stell et al., 2007; 
A
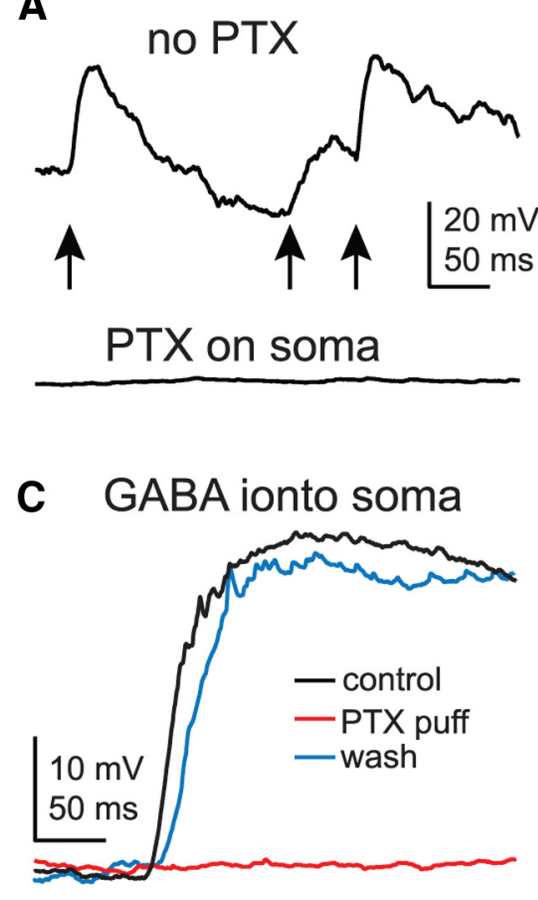

B
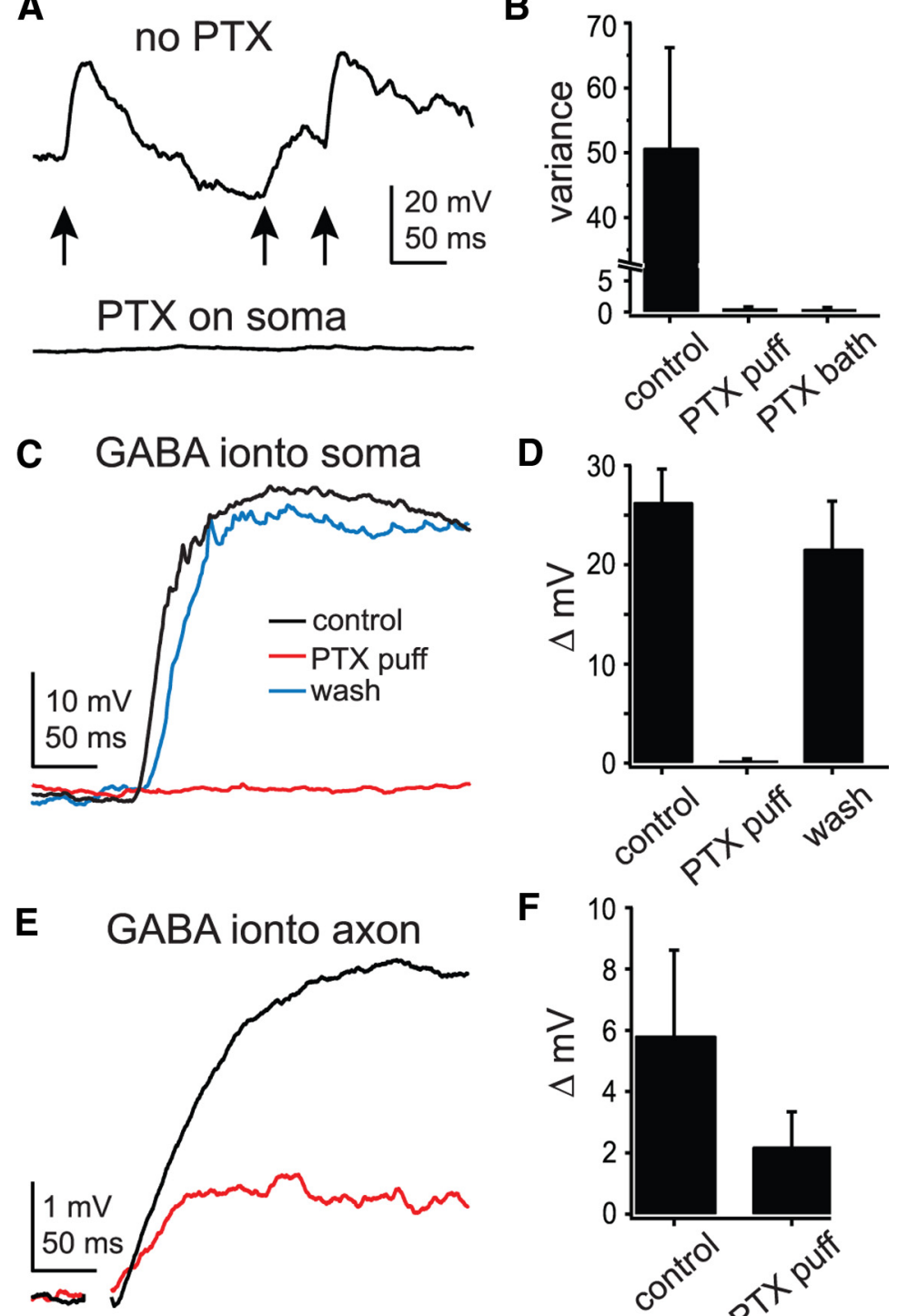

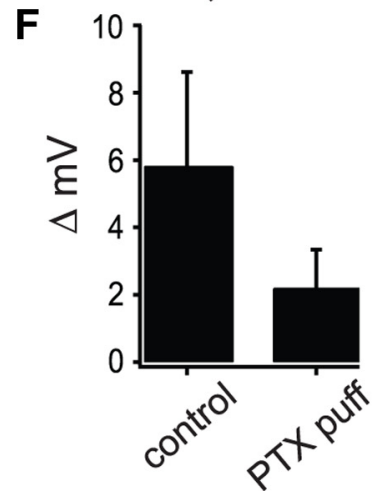

Figure 3. Puffing picrotoxin (PTX) completely blocks somatodendritic $G A B A_{A} R s$ and partially blocks axonal GABA $A_{A} R s$. $A$, Spontaneous IPSPs (arrows) from a granule cell in the absence of picrotoxin (top) or while puffing picrotoxin on the soma (bottom). $\boldsymbol{B}$, Average variance of traces in control, puffing picrotoxin, or bath application of picrotoxin. Example voltage traces $(\boldsymbol{C})$ and average depolarization ( $\boldsymbol{D}$ ) from iontophoresis of GABA onto the soma before (black), during (red), or after (blue) puffing picrotoxin on the soma. Example voltage traces $(\boldsymbol{E})$ and average depolarization $(\boldsymbol{F})$ from iontophoresis of GABA onto the axon before (black) or during (red) puffing picrotoxin on the soma.

Pugh and Jahr, 2011; Dellal et al., 2012). To mimic physiological conditions more closely, we repeated these experiments with a lower-chloride internal $\left(E_{\mathrm{Cl}}\right.$ of $\left.-50 \mathrm{mV}\right)$. In these conditions, activation of MLIs still increased the excitability of granule cells (success rate, $0.42 \pm 0.02$ vs $0.47 \pm 0.02, n=8, p=0.05$; excitability index, $0.15 \pm 0.06$ ). On average, reducing the chloride reversal potential reduced the change in excitability, but this difference was not statistically significant ( $p=0.11$, unpaired $t$ test). These data suggest that release of GABA in the molecular layer is sufficient to activate axonal $\mathrm{GABA}_{\mathrm{A}}$ Rs and enhance firing at the soma.

We then made whole-cell patch-clamp recordings from MLIs to assess the level of ChR2 expression in these cells. In the presence of picrotoxin, five pulse trains of blue light produced only small depolarizations in most cells $(<2 \mathrm{mV}, 10$ of 17 cells; Fig. $1 D$, bottom, $E$ ), suggesting weak ChR2 expression. Furthermore,

APs were observed in only two cells (Fig. $1 D$, top), suggesting that only $\sim 10 \%$ of MLIs fire in response to the light pulses. This indicates that activation of even a small fraction of MLIs is sufficient to activate parallel fiber $\mathrm{GABA}_{\mathrm{A}} \mathrm{Rs}$, depolarize the axon, and increase excitability at the soma.

\section{Activation of MLIs by parallel fiber stimulation}

Using ChR2 to activate MLIs has the advantage of cell specificity, but the disadvantage of poor recruitment of MLIs. Therefore, we decided to recruit MLIs more efficiently by using a train of 10 stimuli at $100 \mathrm{~Hz}$ delivered through a stimulating electrode placed in the molecular layer (NBQX and R-CPP were not included in the bath solution). Molecular layer stimulation produced a large depolarization in granule cells $(11.6 \pm 2.2 \mathrm{mV}$, $n=11$; Fig. $2 A$ ), likely attributable in large part to activation of Golgi cells and their release of GABA onto the soma or dendrites of the granule cell. In fact, granule cells lacking an axon also show large depolarizations in response to molecular layer stimulation $(15.7 \pm 4.1 \mathrm{mV}, n=10$; Fig. $2 C$ ). To isolate the effects of axonal $\mathrm{GABA}_{\mathrm{A}} \mathrm{Rs}$, a $300 \mathrm{~ms}$ puff of $300 \mu \mathrm{M}$ picrotoxin was applied to the soma at the beginning of each sweep. In granule cells with a cut axon, puffing picrotoxin on the soma completely abolished the depolarization during the stimulus train $(-0.05 \pm 0.19 \mathrm{mV}$; Fig. 2C,D). However, in cells with an intact axon, a small residual depolarization remained $(0.38 \pm 0.1$ $\mathrm{mV}$; Fig. $2 A, D)$. To determine the effects of the residual depolarization on firing, we again performed excitability testing by pairing somatic current injections with trains of 10 stimuli at $100 \mathrm{~Hz}$ in the molecular layer on alternating sweeps. Molecular layer stimulation significantly increased excitability at the granule cell soma (success rate, $0.43 \pm 0.02$ vs $0.55 \pm 0.03, n=9, p=0.001$; excitability index, $0.33 \pm 0.06$; Fig. $2 B, E$ ). When all $\mathrm{GABA}_{\mathrm{A}} \mathrm{Rs}$ were blocked by bath application of picrotoxin, molecular layer stimulation had no effect on granule cell excitability in the same cells (excitability index, $0.08 \pm 0.06, n=6, p=0.25$; Fig. $2 E$ ), indicating that the increased excitability results from activation of axonal receptors and not from direct stimulation of the labeled axon.

To confirm that somatodendritic receptors were completely blocked in the preceding experiments, we took two approaches. First, puffing picrotoxin on the soma abolished spontaneous IPSPs (Fig. $3 A$ ). The variance of the voltage traces was greatly decreased by puffed picrotoxin $\left(50.8 \pm 15.4\right.$ vs $0.63 \pm 0.16 \mathrm{mV}^{2}$, $n=6, p=0.02)$. Subsequent addition of picrotoxin to the bath did not reduce the variance further (Fig. $3 B ; 0.54 \pm 0.16 \mathrm{mV}^{2}$, $p=0.3)$. Second, GABA iontophoresed on the somata of granule 
cells elicited large depolarizations (26.4 \pm $3.3 \mathrm{mV}, n=5$; Fig. $3 C, D)$. These responses were abolished by puffing picrotoxin on the soma $(0.2 \pm 0.2 \mathrm{mV}, n=5)$ and recovered after $\sim 5 \mathrm{~min}$ of washout $(21.6 \pm 4.8 \mathrm{mV}, n=3)$.

Picrotoxin applied to the soma will rapidly diffuse away, possibly blocking axonal $\mathrm{GABA}_{\mathrm{A}}$ Rs as well as somatic receptors . To assess the degree of block, we ionotophoresed GABA on to the axons of granule cells at an average distance of $140.0 \pm 12.9 \mu \mathrm{m}$ from the soma, resulting in a somatic depolarization of $5.8 \pm 2.8$ $\mathrm{mV}$. Puffing picrotoxin on the soma reduced the response to $2.2 \pm 1.1 \mathrm{mV}(n=$ 5; Fig. $3 E, F$ ), suggesting that a substantial fraction of axonal $\mathrm{GABA}_{\mathrm{A}} \mathrm{Rs}$ are also blocked by puffing picrotoxin on the soma. Thus, the changes in excitability observed during molecular layer stimulation are likely a significant underestimate of the actual effect when axonal receptors are unblocked.

Measurement of axonal length constant We next estimated the electrical length constant of granule cell axons to determine the distance over which axonal $\mathrm{GABA}_{\mathrm{A}} \mathrm{Rs}$ can influence AP generation. We estimated the effective length constant of these axons by measuring the effects of small somatic depolarizations on the excitability of the axon at varying distance from the soma. Granule cells were voltage clamped with pipettes filled with Alexa Fluor 594 to visualize the axon. A stimulating electrode was positioned next to the labeled axon, and APs were elicited in the axon by brief voltage pulses (Fig. 4A). Despite voltage clamping the soma, APs could be reliably evoked in the axon beyond $\sim 200$ $\mu \mathrm{m}$ from the soma and recorded at the soma as all-or-none action currents (Fig. 4B). On alternating sweeps, axonal stimulation was preceded by a small ( 1 or $2 \mathrm{mV}$ ) depolarization of the soma lasting $300 \mathrm{~ms}$. These relatively small somatic depolarizations increased the probability of AP initiation in the axon as far out as 1000 $\mu \mathrm{m}$ from the soma. To quantify the electrical length constant, the distance between the soma and site of axonal stimulation was varied, and the resulting changes in excitability were measured $(n=8$ sites from 6 cells; Fig. 4C). Fitting the results with a single exponential, we estimated a length constant of $520 \mu \mathrm{m}$ for granule cell axons, in agreement with previous estimates in other neurons (Alle and Geiger, 2006; Shu et al., 2006).

A number of factors other than the length constant may affect how GABA release at different points on the axon influences somatic firing. Therefore, we directly measured the relationship between $\mathrm{GABA}_{\mathrm{A}} \mathrm{R}$ activation at different locations on the axon and the amplitude of the resulting depolarization at the soma. Granule cells were patched in the presence of $500 \mathrm{nM}$ TTX with a high chloride internal solution $\left(E_{\mathrm{Cl}}\right.$ of 0$)$, and RuBiGABA $(100 \mu \mathrm{M})$ was photolytic uncaged by a $5 \mathrm{~ms}$ light pulse from a $473 \mathrm{~nm}$ laser or LED centered on the labeled axon at $\sim 100$ $\mu \mathrm{m}$ steps along the axon (Fig. $4 D, E$ ). Depolarizations of the soma were several millivolts after uncaging on the proximal axon (100 $\mu \mathrm{m}, 3.7 \pm 0.6 \mathrm{mV}, n=10)$ and could be detected after GABA uncaging on the axon at least $400 \mu \mathrm{m}$ from the soma (Fig. $4 F)$. Uncaging responses on the soma or axon were abolished by bath application of $100 \mu \mathrm{M}$ picrotoxin $(18.2 \pm 13.3 \mathrm{vs} 0.1 \pm 0.06$ $\mathrm{mV}, n=3)$. Using a more physiological $E_{\mathrm{Cl}}(-50 \mathrm{mV})$, somatic voltage responses to uncaging on the proximal axon were reduced but not significantly $(3.7 \pm 0.6 \mathrm{mV}, n=10$ vs $2.5 \pm 0.7$ $\mathrm{mV}, n=5 ; p=0.28)$, and responses to uncaging $>200 \mu \mathrm{m}$ from the soma were nearly identical to those using a high-chloride internal $(300 \mu \mathrm{m}, 0.62 \pm 0.21 \mathrm{mV}, n=8$ vs $0.59 \pm 0.08 \mathrm{mV}, n=$ $5, p=0.9$; Fig. $4 F)$. These data indicate that activation of axonal $\mathrm{GABA}_{\mathrm{A}}$ Rs at least $400 \mu \mathrm{m}$ from the soma can produce a measurable depolarization of the soma. Furthermore, these data suggest that, beyond the first couple hundred micrometers, the axon may maintain its own chloride reversal potential regardless of the chloride concentration imposed at the soma.

\section{Discussion}

We find that activation of axonal $\mathrm{GABA}_{\mathrm{A}}$ Rs in cerebellar granule cells by endogenous, synaptically released GABA increases the probability of AP initiation. Axonal receptors were selectively activated by either specific recruitment of MLIs with ChR2 (evoking GABA release only in the molecular layer) or by evoking 
GABA release throughout the cerebellar cortex by electrical stimulation while blocking somatodendric $\mathrm{GABA}_{\mathrm{A}} \mathrm{Rs}$ with local application of picrotoxin. Activation of axonal $\mathrm{GABA}_{\mathrm{A}}$ Rs produced a local subthreshold depolarization that spread passively along the axon to the soma, facilitating AP initiation. However, these data may significantly underestimate the effects of axonal potentials on somatic firing because ChR2 activation recruited only $\sim 10 \%$ of MLIs, and puffing picrotoxin on the soma blocked a significant portion of axonal receptors. The effective length constant of granule cell axons, $\sim 520 \mu \mathrm{m}$, suggests that axonal potentials generated well beyond the parallel fiber branch point can depolarize the soma and influence firing. This was corroborated by the observation that uncaging of GABA directly onto axons up to $400 \mu \mathrm{m}$ from the soma produced a measurable depolarization at the soma. The shorter effective length constant obtained with GABA uncaging may result from increasing tissue depth of the axon at greater distances from the soma and thus decreased light intensity and uncaging efficiency, differences in $\mathrm{GABA}_{\mathrm{A}} \mathrm{R}$ expression density or subunit expression with distance, and changes in intracellular chloride concentration.

To date, few studies have investigated the effects of electrical signaling from the axon back to the soma, although several studies have investigated the effects of presynaptic receptors on axon excitability. For example, tonic activation of presynaptic $\mathrm{GABA}_{\mathrm{A}}$ Rs modulates excitability of presynaptic terminals of the pituitary gland (Zhang and Jackson, 1995) and hippocampal mossy fibers (Ruiz et al., 2003). Other studies have shown that phasic changes in membrane potential at the calyx of Held spread back the axon, influencing AP generation up to $800 \mu \mathrm{m}$ away (Paradiso and $\mathrm{Wu}, 2009)$. However, these studies did not address changes in currents or firing at the soma as the result of axonal potentials. Conversely, the group of Alain Marty has shown that autocrine activation of presynaptic $\mathrm{GABA}_{\mathrm{A}} \mathrm{Rs}$ in the axons of cerebellar stellate cells during development produces kinetically distinct IPSCs at the soma (Pouzat and Marty, 1999; Trigo et al., 2010) and, in some cases, additional AP firing (Mejia-Gervacio and Marty, 2006). Our previous work has demonstrated that activation of axonal $\mathrm{GABA}_{\mathrm{A}}$ Rs by exogenous GABA can affect AP firing in cerebellar granule cells (Pugh and Jahr, 2011). This result was confirmed by a computer modeling study of axonal $\mathrm{GABA}_{\mathrm{A}} \mathrm{R}$ activation and AP initiation in the same cells (Dellal et al., 2012). To our knowledge, the present work is the first showing that activation of axonal receptors by release of neurotransmitter from nearby synapses can affect integration and AP initiation at the soma.

\section{Effects on signaling in the cerebellar circuit}

Parallel fiber synapses onto Purkinje cells are notable for their relatively low release probability coupled with large facilitation (Perkel et al., 1990; Dittman et al., 2000). This produces a synapse at which single APs are transmitted poorly whereas bursts of APs are transmitted remarkably well. Because of the facilitating nature of the synapse, each additional AP disproportionately increases the postsynaptic response. Excitatory feedback from granule cell axons to the soma may increase the number of APs in a burst or turn single APs into a burst, significantly enhancing transmission and postsynaptic responses at parallel fiber synapses.

The spread of axonal potentials back to the soma of granule cells may also act as a homeostatic mechanism that helps to maintain the balance of excitation and inhibition in the cerebellar cortex. For example, excessive GABAergic activity in the molecular layer would tend to reduce or prevent firing in Purkinje cells.
However, this inhibition may be at least partially offset by an increase in excitatory synaptic input attributable to activation of parallel fiber $\mathrm{GABA}_{\mathrm{A}} \mathrm{Rs}$ and the resulting increase in release probability at parallel fiber synapses (Stell et al., 2007; Pugh and Jahr, 2011) and AP firing at the granule cell body. Conversely, diminished GABAergic activity in the molecular layer may produce excessive firing in Purkinje cells while at the same time reducing $\mathrm{GABA}_{\mathrm{A}} \mathrm{R}$ activation in parallel fibers, resulting in reduced excitatory input to Purkinje cells. The homeostatic balance of tonic excitation and inhibition in the cerebellar cortex mediated by parallel fiber $\mathrm{GABA}_{\mathrm{A}} \mathrm{Rs}$ may help Purkinje cells maintain firing within their optimal dynamic range, allowing for phasic changes in firing in response to behavioral stimuli.

\section{References}

Alle H, Geiger JR (2006) Combined analog and action potential coding in hippocampal mossy fibers. Science 311:1290-1293. CrossRef Medline

Christie JM, Chiu DN, Jahr CE (2011) Ca(2+)-dependent enhancement of release by subthreshold somatic depolarization. Nat Neurosci 14:62-68. CrossRef Medline

Dellal SS, Luo R, Otis TS (2012) GABA $_{\mathrm{A}}$ receptors increase excitability and conduction velocity of cerebellar parallel fiber axons. J Neurophysiol 107: 2958-2970. CrossRef Medline

Dittman JS, Kreitzer AC, Regehr WG (2000) Interplay between facilitation, depression, and residual calcium at three presynaptic terminals. J Neurosci 20:1374-1385. Medline

Eccles JC (1964) The physiology of synapses. Berlin: Springer.

Hull C, Regehr WG (2012) Identification of an inhibitory circuit that regulates cerebellar Golgi cell activity. Neuron 73:149-158. CrossRef Medline

Mejia-Gervacio S, Marty A (2006) Control of interneurone firing pattern by axonal autoreceptors in the juvenile rat cerebellum. J Physiol 571:43-55. CrossRef Medline

Paradiso K, Wu LG (2009) Small voltage changes at nerve terminals travel up axons to affect action potential initiation. Nat Neurosci 12:541-543. CrossRef Medline

Perkel DJ, Hestrin S, Sah P, Nicoll RA (1990) Excitatory synaptic currents in Purkinje cells. Proc Biol Sci 241:116-121. CrossRef Medline

Pouzat C, Marty A (1999) Somatic recording of GABAergic autoreceptor current in cerebellar stellate and basket cells. J Neurosci 19:1675-1690. Medline

Pugh JR, Jahr CE (2011) Axonal GABA $A_{A}$ receptors increase cerebellar granule cell excitability and synaptic activity. J Neurosci 31:565-574. CrossRef Medline

Ruiz A, Fabian-Fine R, Scott R, Walker MC, Rusakov DA, Kullmann DM (2003) GABAA receptors at hippocampal mossy fibers. Neuron 39:961973. CrossRef Medline

Schmitz D, Mellor J, Nicoll RA (2001) Presynaptic kainate receptor mediation of frequency facilitation at hippocampal mossy fiber synapses. Science 291:1972-1976. CrossRef Medline

Shu Y, Hasenstaub A, Duque A, Yu Y, McCormick DA (2006) Modulation of intracortical synaptic potentials by presynaptic somatic membrane potential. Nature 441:761-765. CrossRef Medline

Stell BM (2011) Biphasic action of axonal GABA-A receptors on presynaptic calcium influx. J Neurophysiol 105:2931-2936. CrossRef Medline

Stell BM, Rostaing P, Triller A, Marty A (2007) Activation of presynaptic $\mathrm{GABA}_{\mathrm{A}}$ receptors induces glutamate release from parallel fiber synapses. J Neurosci 27:9022-9031. CrossRef Medline

Trigo FF, Bouhours B, Rostaing P, Papageorgiou G, Corrie JE, Triller A, Ogden D, Marty A (2010) Presynaptic miniature GABAergic currents in developing interneurons. Neuron 66:235-247. CrossRef Medline

Turecek R, Trussell LO (2001) Presynaptic glycine receptors enhance transmitter release at a mammalian central synapse. Nature 411:587-590. CrossRef Medline

Zhang SJ, Jackson MB (1995) $\mathrm{GABA}_{\mathrm{A}}$ receptor activation and the excitability of nerve terminals in the rat posterior pituitary. J Physiol 483:583-595. Medline

Zhao S, Ting JT, Atallah HE, Qiu L, Tan J, Gloss B, Augustine GJ, Deisseroth K, Luo M, Graybiel AM, Feng G (2011) Cell type-specific channelrhodopsin-2 transgenic mice for optogenetic dissection of neural circuitry function. Nat Methods 8:745-752. CrossRef Medline 